Vol. 4, No. 2, 2017

https://doi.org/10.23939/eem2017.02.069

UDC 338.48

O. Muzychenko-Kozlovska

$\mathrm{PhD}$ in Economics, Associate Professor

A. Symak

$\mathrm{PhD}$ in Economics, Associate Professor

Lviv Polytechnic National University

\title{
THE ESSENCE AND METHODICAL APPROACHES TO THE EVALUATION OF THE TOURIST POTENTIAL OF THE TERRITORY
}

\begin{abstract}
The contemporary content is disclosed and the possibility of using the term "tourist potential of the territory" is explained. My position on the content of the concept "tourist potential of the territory" is formulated. The complex approach to estimation of tourist potential of a locality with consideration of its components and indicators is offered.

Key words: potential, tourist potential of the territory, components and indicators of assessment of the tourist potential of the area.

\section{Introduction}

Tourism activity plays an important role in the development of the Ukrainian economy, creating additional benefits and opportunities for the local population, especially if the activity is carried out on a permanent basis. Indeed, sustainable development envisages economic growth on the basis of the interests of the population and a thriving attitude towards the environment.

The tourist industry is a very diverse branch of the economy that it covers up to 50 sectors of the economy, including transport, construction, trade, catering, agriculture, housing and communal services, culture, art, sports etc. thus creating the multiplier effect.

Tourism is one of the spheres of the economy that is clearly tied to the territory where it is being conducted. The natural and other resources of this locality are the basis for it. To effectively manage the development of tourism and determine the necessary investment it is necessary to find out its capabilities within a certain territory.
\end{abstract}

\section{Analysis of latest researches and publications}

Numerous works of scientists and practitioners are devoted to problems that arise in the study of tourism potential and its components. For instance, M. P. Butko [1] defined the place of the tourist potential in the economic space; V.V. Shmahina [2] developed a comprehensive assessment of the factors of the natural resource potential of the recreational and tourist complex; V. Poliuha [3] improved the system of statistical indicators of the tourist and recreational industry; V.I. Matsola [4] uses natural and cost indicators to assess the potential of the recreation and tourism complex in the region; O. Hulych [5] gives a description of the recreational potential of the Ukrainian Carpathian Mountains; A. Abdulla, M. Sumen [6] developed a methodology for assessing tourism potential based on demand and supply; V. M. Kozyriev [7] considers the touristrecreational potential through the prism of the possibility of obtaining income by economic subjects whereas A. S. Kuskov [8] considers it through the prism of non-violation of ecological balance. However, scientists did not manage to create the only methodology for evaluating the tourist potential. Thus, the problem needs further study.

\section{Goals}

The aim of the article is to reveal the present essence and formulate own opinion on the content of the concept of "tourism potential of the 


\section{O. Muzychenko-Kozlovska, A. Symak}

territory"; identify the components and justify the approach to assessing the tourism potential of the territory.

\section{Presentation of main material}

The interest of scientists in this issue increases each year due to the dynamism of tourism development and its importance for the economy of the country and regions. Therefore it is necessary to clarify the conceptual apparatus which concerns tourism activity and tourism potential in particular.

Thus, one can find in scientific works the terms "tourist-recreational potential", "recreational and tourist potential", "tourist potential", "tourist resources" under which identical concepts are often understood.

It is worth to analyze the meaning of the term "potential" before finding out the essence of the concept of "tourist potential".

Potential (from lat. potentia - force) is a collection of all available means, capacities, productive forces, etc. that can be used in any industry, sector, sphere [9].

Potential is the available capabilities, resources, stocks and means that can be used to achieve or carry out something [10, p. 211].

Different terms are understood under the tourist potential in scientific literature, for example: "tourist resources", "tourist fund", "tourist heritage", "tourist attraction", sometimes this concept is identified with "tourist-recreational potential" or "recreational and tourist potential".

In order to find out the difference between these definitions, it is worth mentioning that according to Ukrainian legislation "tourism is a temporary departure of a person from the place of residence for health, cognitive, professional, business or other reasons without carrying out paid activities in the place where the person arrives" [11].

"Recreation is restoration of mental, spiritual and physical abilities of the person in the places of the protected areas and objects outside the permanent place of residence determined by the legislation. Recreation is carried out through general health, cultural and educational rest, tourism, amateur and sport fishing activities... etc." [12].

Thus, recreation includes tourism activities. So, there is no need to expand the concept of "tourist potential", which is wider than recreational, because tourism is divided into such "types as sports; religious; ecological (green); rural; business as well as cultural-cognitive and health-improving" [11], etc.

Let us explain the definitions of the concept of "tourism potential" given by different scholars and practitioners.

S. V. Dutchak gives the following definition: "Tourist potential is a cultural and historical heritage being an anthropogenic component of tourism, as well as certain landscape complexes where tourism activity takes place, with some natural or man-made tourist objects or events that tourists visit, in particular: museums, cultural monuments, architecture, traditions of the population, folk crafts, etc." [13].

P. F. Koval explains that the tourist potential of the territory is a capacious, multidimensional concept that consists of a set of natural, ethnocultural and socio-historical resources, as well as the existing economic and communication infrastructure of the territory that serve or may serve as prerequisites for the development of certain types of tourism [14].

S. I. Dorohuntsov suggests the following definition: "Tourist potential is the ability of economic entities and authorities to form a tourist product of the territory by using all resources for the development of the territory in order to meet the needs of the population and target markets" [15].

J. Crippendorf considers tourist potential through the prism of the possibility of creating a "finite tourist product" and the ability to develop economic tourism [16].

The existing definitions of "tourist potential" can be called into question if one considers the wording using integrated approach, under which all the components of the term should be taken into account. Such a multi-sided concept can be characterized in the following way.

Potential is only opportunities that can be used to create the necessary conditions, that is, infrastructure, information base, security environment, etc.

The tourist potential of the territory includes such components as technical tourism potential and economic tourism potential. The technical tourist potential is the ability of the territory to attract the maximum number of tourists that can find tourist 
accommodation or stay at residents' places of a certain region with available tourist resources, taking into account the possible recreational and psychological pressure on the area. Economic tourism potential is an economically efficient number of tourists who visited a certain region and made it possible to achieve maximum socioeconomic effect.

The real tourist potential of the territory is a natural and anthropogenic tourist resources of the territory, as well as a modern developed material and technical base of tourism (MTB) which makes it possible to attract the maximum number of tourists that can find tourist accommodation or stay at residents' places of a certain region with available tourist resources taking into account permissible recreational and psychological pressure on this area in order to achieve maximum socioeconomic effect.

One can use indicators presented in the statistical reporting of tourist enterprises or other institutions in order to estimate the technical tourist potential of the territory. Using statistical indicators the number of facilities and their locations can be calculated to find out how many tourists can visit a specific region. Thus, the actual state of tourism development in a particular area can be defined.

In order to determine the economic tourism potential it is necessary that the set of factors influencing the achievement of the maximum economic efficiency of tourism activity and the measures to be taken to achieve it (in order to achieve maximum economic effect) should be considered. There may be potential for tourism development and the desire to receive the maximum number of tourists in a given region, but the costs for this may be inappropriate in order to achieve the maximum economic effect. The area with available tourist resources can be attractive to potential tourists to some extent. But such a territory will not achieve the high level of tourist attraction. After all, in order to create a tourist center it is important that all components of this process, such as MTB tourism, tourism infrastructure or marketing policy should be developed.

It is necessary to specify the components of this process in order to select the method of estimating the tourist potential of the territory. We suggest a list of elements given in the table that are a part of this or that component which form the environment and the system for ensuring the formation of the tourist potential of the territory. It is obvious that each of the components in the table reflects the factors that influence the formation of the tourist potential of the territory, the conditions for the needs of potential tourists, etc. The analysis and evaluation of each component will allow you to go over to the list of lower-level indicators that are predominantly represented by a system of statistical indicators (in case of absence of statistics, some lower-level indicators can be estimated in points by experts).

However, there are many factors having a significant impact on the development of tourism in the area are the basis for the activities of tourism enterprises while the quantitative indicators for their evaluation in statistical data are not reflected.

This situation has arisen due to the uncertainty of the tourism industry as a separate branch of economy in the National Classifier of Ukraine "Classification of Types of Economic Activity DK 009: 2010" [17]. There are only certain types of economic activity related to tourism mentioned in the named Classifier. Tourism in this classification is a part of the services sector. This point should be corrected by defining tourism activity as a separate branch of the Ukrainian economy, which would enable it to better manage this process, and hence the opportunity to increase the use of the tourist potential of the territory.

Table 1

The composition of components of the tourist potential of the territory

\begin{tabular}{|c|c|c|}
\hline \multicolumn{2}{|c|}{ Components } & Elements \\
\hline \multirow{5}{*}{ 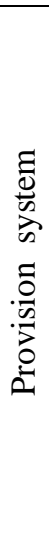 } & \multirow[t]{3}{*}{$\begin{array}{l}\text { Basic } \\
\text { constituents }\end{array}$} & Natural tourist resources \\
\hline & & $\begin{array}{l}\text { Tourist resources of } \\
\text { anthropogenic origin: historical } \\
\text { and architectural monuments, } \\
\text { cultural, religious values etc. }\end{array}$ \\
\hline & & $\begin{array}{l}\text { MTB: tourist infrastructure, } \\
\text { investment support of industry }\end{array}$ \\
\hline & \multirow{2}{*}{$\begin{array}{l}\text { Additional } \\
\text { constituents }\end{array}$} & Labor resources \\
\hline & & $\begin{array}{l}\text { Marketing support: pricing } \\
\text { policy, information support }\end{array}$ \\
\hline
\end{tabular}




\section{O. Muzychenko-Kozlovska, A. Symak}

Therefore, some indicators from the specialized literature can be used. Such indicators are: the area occupied by recreational resources and the number of anthropogenic or other resources.

The study of tourism activity opportunities is carried out with the help of various approaches depending on the purpose of the research: regional, economic, ecological, historical, systemic etc. In order to assess the tourism potential of the region it is most appropriate to use a systematic approach that combines all other approaches into a single integrated method and consider the problem as a complex system. Thus, it is possible to take into account the peculiarities of the use of the existing basic components of the tourism potential: the natural and anthropogenic resources of the territory, the level of development of tourism MTB in the region as well as additional components: labor resources and marketing policy.

It is possible on the basis of the integrated approach to explore the territory with available tourism potential for the purpose of conducting tourist activity there, expansion or reduction of tourism MTB taking into account the recreational and psychological pressure on tourist facilities, to ground tourism development programs etc. The ability to provide management bodies with information for the coherence of different decisions in terms of directions (production, financial or marketing) as well as at the strategic, tactical or operational levels and continuity of managerial decisions show the advantage of a systematic approach in the analysis of the tourist potential of the territory.

We will have the opportunity to fulfill the following research objectives with the help of the established system of indicators of evaluation of the tourist potential of the territory: quantitatively and qualitatively assess the level of development of the tourism industry in different areas; to cover the causal links in the process of determining the level of development of the tourism potential of the territory; to identify the factors that influence the development of tourism activities, including those that have a destabilizing effect on the tourism industry, the possibility of predicting a change in tourism activity due to the influence of destabilizing factors and the adoption of optimal managerial decisions on their basis. The system of indicators will make it possible to compare the potential of the development of various tourist areas and to make the best decision regarding the possibility of obtaining the socio-economic effect from their development.

We select indicators that characterize the components of the tourism potential of the territory basing on the existing practice of statistical reporting.

Indicators for evaluating elements of the "natural tourism resources" component may be:

- quantity of natural resources by categories on the territory;

- development of natural tourism resources;

- recreational capacity within a certain territory.

The following indicators are possible for the element "anthropogenic tourism resources':

- concentration of cultural and historical monuments on the territory;

- quantity of cultural-historical monuments by the level of significance (world, national, local);

- necessary and sufficient time to review the values in order to compare different territories with the prospect of historical and cultural potential for tourism;

- state of cultural-historical monuments preservation.

The following indicators describe an element of the "MTB Tourism" component:

- amount of tourists accommodation for different categories of tourists;

- the number of beds for accommodation of tourists;

- coefficient of occupied tourist accommodation facilities;

- profit per one bed in tourists accommodation;

- number of employees in tourist accommodation per one thousand provided bed-days;

- average dwelling space of tourist accommodation in one place.

These are the elements of the marketing policy component:

- prices for services at tourist enterprises;

- advertising expenses.

We suggest the following indicators for an element of the "labor resources" component:

- number of employees of the tourist industry in the region; 
- dynamics of the number of labor resources;

- the number of educational institutions that train the specialists of the tourism profile.

All these indicators are independent and only a cumulative their analysis allows to estimate the tourist potential of the territory.

Therefore, it is worth applying a comprehensive approach to evaluate the tourist potential of the territory.

\section{Conclusions and perspectives of further} research

The research carried out in this article made it possible to state:

1. The real tourist potential of the territory is a natural and anthropogenic tourist resources of the area as well as a modern developed material and technical base of tourism with the help of which you can attract the number of tourists that tourist accommodation or residents of a certain region with available tourist resources can place, taking into account the permissible recreational and psychological pressure on this area in order to achieve maximum socio-economic effect.

2. Natural and anthropogenic tourist resources, material and technical base of tourism, labor resources and marketing support are the elements of the components which create the environment for the formation of tourist potential of the territory.

3. It is most appropriate to use a systematic approach that allows combining all other approaches into a single, integrated method, and consider the problem as a complex system to estimate the tourism potential of the region.

It is advisable to propose a methodology for estimating the tourist potential of the territory in further research.

\section{References}

1. Butko M. P. (2009). Henezys ekonomichnoii teorii ta metodolohichni pidkhody do otsinky turystychnoho potentsialu rehionu [The Genesis of Economic Theory and Methodological Approaches to the Assessment of Tourism the potential of the region]. Retrieved from http://tourlib.net/statti_ukr/butko.htm. [in Ukrainian]

2. Shmahina V. V. (2001). Mekhanizmy mobiizatsiii pryrodno-resursnoho potentsialu rozvytku rekreatsiii ta turyzmu (na prykladi Ukraiinskoho
Prychornomoria) [Mechanisms for mobilizing the natural resource potential of recreation development and tourism (on the example of the Ukrainian Black Sea coast)] (Extended Abstract of Cand. Agric. Sci. Diss.). Instytutt probl. rynku ta ekon-ekol. Doslidzh, Odesa, Ukraine. Retrieved from http://tourlib.net/aref_tourism/ shmagina.htm. [in Ukrainian]

3. Poliuha, V. (2001). Aspekty statystychnoho vyvchennia stanu turystychnoii haluzi rehionu / V. Poliuha // Rehionalna ekonomika [Regional economics], 2, 176-180. [in Ukrainian]

4. Matsola V. I. (1996). Formuvannia i rozvytok rekreatsiino-turystychnoho kompleksu Zakarpatskoii oblasti [Formation and development of recreation and tourist complex Transcarpathian region] (Extended Abstract of Cand. Agric. Sci. Diss.). Instytut rehionalnykh doslidzhen, Lviv, Ukraine. [in Ukrainian]

5. Hulych O. I. (2004). Rekreatsiinyi potentsial Ukraiinskykh Karpat ta suchasnyi stan yioho osvoiennia. In-t rehion. doslidzh. NAN Ukrayinu [Institute for Regional Studies]. Lviv, 56 p. [in Ukrainian]

6. Abdulla, A., Sumen, M. (2012). Methodology of assessment of tourism potential: an example of Murshidabad district, West Bengal, India [International Journal of Scientific and Research Papers], 2 (9).

7. Kozyriev, V. M. (2003). Turistskia rienta. Finansy $i$ statistika [Finances and statistics], Moscow. [in Russia]

8. Kuskov, A. S., Lysikova O. V. (2004). Kurortologiia $i$ ozdorovitelnyi turizm [Health resorts and health tourism]. Rostov na Donu: Feniks, 320 p. [in Russia]

9. Busel, V.T. (2009). Velykyi tlumachnyi slovnyk suchasnoii ukrayinskoii movy (z. dod., dopov. na CD) [Great explanatory dictionary of modern Ukrainian language] (1736 p.). Kyiv.: Irpin: VTF Perun. [in Ukrainian]

10. Mazaraki, A. A., Bokhan, A. V., Holovnia, Yu. I., Budziak, V. M., Madzhalii, S. M. (2012). Rehionalna ekonomika: slovnyk terminiv [Regional Economics: Glossary of Terms]. Kyiv: Kyiv nats. torh.-ekon. un-t, 352 p. [in Ukrainian]

11. Zakon Ukrayiny "Pro turyzm" [Law of Ukraine "On Tourism"]. Retrieved from http://zakon2. rada.gov.ua/laws/show/324/95-

$\%$ D0 \%B2 \%D1 \%80. [in Ukrainian]

12. Pro zatverdzhennia Polozhennia pro rekreatsiinu diialnist $u$ mezhakh terytorii ta obiektiv pryrodno-zapovidnoho fondu Ukrayiny. (2009). 


\section{O. Muzychenko-Kozlovska, A. Symak}

Nakaz Ministerstva okhorony navkolyshnioho seredovyshcha Ukrayiny vid 22.06.2009 [Order of the Ministry of Environmental Protection the natural environment of Ukraine dated 22.06.2009], 330. Retrieved from http://zakon3. rada.gov.ua/laws/show/z0679-09. [in Ukrainian]

13. Dutchak, S. V. (2011). Upravlinnia rehionalnym rozvytkom turyzmu [Management of regional tourism development]. - Chernivtsi. Chernivetskyi natsion. un-t, 128 p. [in Ukrainian]

14. Koval, P. F., Alieshugina, N. O., Andreieva, H. P. (2010). Vyiznyi turyzm: navhalnyi posibnyk [Outbound tourism]. Nizhyn, Vydavnytstvo Lukianenko V. V., 304 p. [in Ukrainian]
15. Dorohuntsov, S. I., Khvesyk M. A., Horbach, L. M., Pastushenko, P. P. (2006). Ekoseredovyshche $i$ suchasnist. - T. 1. Pryrodne seredovyshche u suchasnomu vymiri [Eco-environment and modernity. - T. 1. Natural environment in modern measurements]. Kyiv: Kondor, 424 p. [in Ukrainian]

16. Crippendorf, J. Martin Freddenverker. (1980). 2 aufl. Bern; Frankfurt am Main, 168 p. [in German]

17. Natsionalnyi klasyfikator Ukrayiny "Klasyfikatsiia vydiv ekonomichnoi diialnosti” $D K \quad 009$ [National Classifier of Ukraine "Classification of Types of Economic Activities" DK 009]. (2010). Retrieved from http://dkrp.gov.ua. [in Ukrainian] 